EUROPEAN JOURNAL O ENVIRONMENT
European Journal of Environment and Public Health, 2018, 2(2), 08

ISSN: $2468-1997$

\title{
Public Health and Well-being Innovation in the Natural Environment Sector: Lessons from the UK and Finland
}

\author{
John Tredinnick-Rowe ${ }^{1 *}$, Timothy Taylor ${ }^{1}$, Anja Tuohino ${ }^{2}$ \\ ${ }^{1}$ University of Exeter, Room 207, 11 Kirkby Place, Drake Circus, PL4 8AA Plymouth, UNITED KINGDOM \\ ${ }^{2}$ University of Eastern Finland, FINLAND
}

*Corresponding Author: john.tredinnick-rowe@plymouth.ac.uk

Citation: Tredinnick-Rowe, J., Taylor, T. and Tuohino, A. (2018). Public Health and Well-being Innovation in the Natural Environment Sector: Lessons from the UK and Finland. European Journal of Environment and Public Health, 2(2), 08. https://doi.org/10.20897/ejeph/3904

Published: September 28, 2018

\begin{abstract}
Thirty-one ethnographic interviews were conducted with health and well-being sector businesses to examine the dynamics of innovation in the UK (Cornwall) and across Finland. The Nordic countries are at the leading edge of these types of public health nature-based interventions, consequently, Finland was chosen as a comparator to the UK. We found that the construction of natural environment based services for health and well-being follows a five-step model: (1) Services are specifically designed for individuals' needs; (2) These services are based around routine behaviours of that individual and their personal and social habits; (3) This creates a process of normalisation that relates to former states of health prior to being ill; (4) These routines generally function at a habitual level if they are to be of use on a daily basis (we are not conscious of all of our actions all the time); and (5) nature is used to embed these new routines because it allows access to the latent forms of thought, not ones that require direct conscious learning. We found this emergent process closely resembles Pierre Bourdieu's concept of habitus. A number of health and well-being businesses have moved towards mixed models of service provision- combining profit-making activities in the tourism and leisure markets with care services to create a sustainable service model in response to increasing pressures on funding sources. However, more still needs to be done in terms of training for public health and well-being businesses if this service model is to become financially sustainable for all.
\end{abstract}

Keywords: green space, Finland, Blue Space, Bourdieu, innovation

\section{INTRODUCTION}

This paper compares and contrasts organisations in the UK and Finland in terms of their innovative positioning (Francis and Bessant, 2005) and use of the natural environment to promote public health and well-being. This study addresses two distinct European policy issues, firstly, the increased cost of prescription medicine, and secondly the preservation (and so use) of natural environments. It was felt that if successfully identified, a social prescribing approach to mental and physical health that utilises the natural environment could reduce the cost (and use) of prescription medication to tax payers \& patients, whilst also promoting (and demonstrating the value) the use of green and blue spaces (Husk et al., 2018). Such a solution could form the basis of a service model for the use of natural environments to promote human health, alleviating the economic burden associated with producing pharmaceuticals, and providing an economic incentive to preserve natural environments - positioning them as health and well-being resources (Tidd and Bessant, 2011). 
More specifically, it is known that a substantial number of the companies who run interventions in the environmental human health sector are 'lifestyle entrepreneurs' who have built businesses around their pursuits of traditional outdoor activities, such as in Finland's expansive forests and lakes (Hjalager et al., 2008; Kelly, 2010; Hjalager and Nordin, 2011; Pikkemaat, 2008). Williams et al. (1989) note such organisations tend to have high failure rates, largely due to limited interest or experience in how to effectively administer such services, or financially manage a business.

This has implications for the users of health intervention but also financial consequences for state-funded health providers who contract these organisations. The need for analysis of the determinants of the success of health interventions is required, if such services are to be replicated in different contexts. Moreover, for the natural environment's beneficial role in health to be realised, a financially sustainable service model needs to be determined.

Given this, we conducted thirty-one ethnographic interviews in the United Kingdom (using businesses located in Cornwall) and Finland to examine the dynamics behind innovation in this sector. This data provided a broad spectrum of opinion (expert and practitioner) on how innovation occurs in organisations that use natural environments to increase public health and well-being. The following sections of this paper cover the genesis of natural environment use for health, research methods, and analysis, and background to case studies and an extensive data section, which covers the themes that emerged from the interviews in Cornwall and Finland. This is followed by a discussion of the findings and methodological limitations. The paper concludes with a summation of the inter-sectoral linkages between tourism, the environment and health.

\section{ENVIRONMENTS AND HUMAN HEALTH}

Epidemiologically, there is significant evidence that exposure to the natural environment improves mental and physical well-being (Ulrich, 1983; Kaplan and Talbot, 1983; Joye and van den Berg, 2011; Herzog et al., 2002; Korpela and Hartig, 1996; Maller et al., 2006; Parsons, 1991; Regan and Horn, 2005; White et al., 2011; Wheeler et al., 2012; Ashbullby et al., 2013; White et al., 2010). Some key European geographies in this regard include Nordic Well-being (Hjalager et al., 2011; Hjalager and Flagestad, 2011) with specific sub-clusters such as 'lake-wellness' (Tuohino, 2013; Konu et al., 2010) or Alpine Wellness in more southerly parts of Europe (Weiermair and Steinhauser, 2003; Pechlaner and Fischer, 2006). More generically, one might talk about Blue space and Green space health interventions, in reference to whether they occur on land or water respectively, which will be introduced further on in this paper, see Section 3 Case Studies. For a comprehensive, systematic review of the topic see Husk et al. (2016). Environmental interventions of this kind exist across a spectrum of envirotypes: pure wilderness, environments subject to human management, and environments entirely created by humans (virtual ${ }^{1}$ and physical) (Bell et al., 2017). Similarly, from the medical perspective interventions run from preventative approaches for stress, fatigue, obesity and social isolation (Thompson et al., 2011); to palliative care or end of life treatment (Kelly, 2016).

Historically, there has been a clear intersection between nature and health (Gesler, 1993; Gesler, 1996), specifically related to therapeutic healing in spa towns and at religious sites (Gesler, 1998; Geores, 1998). Indeed, there is a long hydrotherapeutic history in most European nations, a cultural remnant of the Roman Empire, which formed part of a wider globalised therapeutic landscape (Foley, 2014). These spaces, in addition to their association with hygiene are also frequently sites of religious pilgrimage (Breathnach, 2004). In Europe the often cited origin of this was in $13^{\text {th }}$ century Flanders, at St Dympna's shrine site in Geel, where a community cared for mentally handicapped pilgrims (Bloor et al., 1988).

The $18^{\text {th }}$ century saw the popularisation of spa towns, in the UK and across European nations (Porter, 1999), which adhered to the benefits of fresh air, a treatment that became known as open air treatment (Bryder, 1992). Institutionally, the perceived medical benefits of fresh air were used both in asylums (Smyth, 2005; Parr, 2007) and tuberculosis hospitals (Bird, 2007). As Frumkin (2001: 236) states, "hospitals have traditionally had gardens as an adjunct to recuperation and healing". This phenomenon can be traced back to medieval hospitals and monasteries, which used courtyards and gardens as a source of respite and as an aesthetic feature (Bird, 2007; Nightingale, 2010; GerlachSpriggs et al., 2004).

Arguably, the propagation of such services could be tied to the Victorian proclivity to romanticise nature as a vessel for the renewal of mental, physical and spiritual health (Hickman, 2013). This was thought to be a reaction to the on-going industrialisation of the country at the time (Thorsheim, 2006; Gaskell, 1980). It was at the turn of the 19th century that Blake (1998: 205) famously penned: 'And was Jerusalem builded here, Among these dark Satanic Mills?' capturing the vox populi of the time. These themes are still identifiable today in natural environment discourses, highlighting the importance of the Victorian period in positioning the natural environment.

${ }^{1}$ For an extended discussion about classification of different environment types see Kull (1998) 
From these early stages, we can see that hospitals, just as they function now, cared for both mental and physical conditions. In the same manner there is also a history of natural environment based therapy to be found in sanatoriums and asylums. This is a distinctly Victorian activity, being used as a form of employment for those on asylum farms to prevent them "languish [ing] away their lives within the walls of the hospital" (Rush, 2003: 226). In this era there was also a strong moralism attached to the concept of therapeutic uses of natural environments in parks and sanatoriums (Driver, 1988).

Beyond institutions there are indications that this intersection has become a priority for government departments to consider as well, such as for National Parks (National Parks, 2012), forestry (Forestry Commission 2004, 2006), and heritage (Natural England, 2012). Similarly, in the private sector innovation in the tourism and leisure industry around the health and well-being benefits of nature is undergoing somewhat of a renaissance. Including the growth of spa tourism (Mintel, 2011) and developments in Green Care (Berget et al., 2012).

The current governmental interest in this area is highly differentiated from the moralism of the Victorians. The push towards natural environment based health interventions is to encourage citizens not to be a burden on state health services, in an effort to curtail the running costs of the health sector (LeBesco, 2010). To illustrate in practice what green space and blue provision exist, several examples will be outlined here.

\section{Care Farms}

Care farming since its inception has moved into a fully-fledged activity in itself, rather than just being associated with hospitals or asylums. Sometimes termed social farming, care farming is the use of land (commercial and noncommercial) as a mechanism for the development of physical and mental health through farm work (Hassink, 2002; Hassink and van Dijk, 2006). Care farming activities are directed at a range of conditions both mental and physical. Common service users include adults with learning difficulties or depression, disaffected persons, dementia patients, drug rehabilitation and stress cases.

\section{Domestic and Non-domestic Animals}

Although not overly common in the UK, the use of animals in natural environment based therapies such as care farming is prominent is some European countries, especially Finland (Berget et al., 2012). The use of animals for rehabilitation and therapeutic purposes, like the use of the natural environment, has a long history and can be found in many forms and for many specific purposes. The use of animals for specific interventions is known as Animal Assisted Intervention (AAI) (Kruger and Serpell, 2006). Less directed forms of therapy are known as Animal Assisted Activities (AAA) which can include such concepts as companion animals (Fine, 2006; Wood et al., 2005; Straede and Gates, 1993; Beck and Meyers, 1996).

\section{Horticulture}

The social and psychological benefits of horticulture are well attested (Sempik and Aldridge, 2005; Sempik et al., 2002; Gonzalez et al., 2009; Stigsdotter and Grahn, 2002). Similar to the use of animals for therapeutic purposes, horticulture has two distinct forms for the promotion of public health and well-being. These are therapeutic horticulture and horticultural therapy. The distinction between the two is best described by Growth Point (1999):

"Horticultural therapy is the use of plants by a trained professional as a medium through which certain clinically defined goals may be met...

Therapeutic horticulture is the process by which individuals may develop well-being using plants and horticulture. This is achieved by active or passive involvement." P4

Again, the distinction between the two concepts comes from the application of a specific goal or in the case of therapeutic horticulture, therapy being applied in a more generalised sense. As has been mentioned elsewhere, therapeutic horticulture is found in hospital gardens (Hartig and Marcus, 2006), and for schools, prisons (Ormerod, 2008) and care homes (Lewis, 1990). Horticultural therapy is used for people with enduring mental conditions who require increased expression, confidence, self-esteem and group interaction (Parker, 2004), the rationale being that plants and horticultural activities provide a non-threatening, non-judgemental environment (Lewis, 1996).

\section{Green Exercise}

The physical benefits of exercise have been well-studied (DoH, 2004); however it was not until more recently that the physiological role became known. Studies have shown links to a reduction in stress (Dunn et al., 2005; Sims et al., 2009) anxiety and eating disorders (Stathopoulou et al., 2006), post-traumatic stress (Diaz and Motta, 2008) and depression (Townsend, 2006). The obvious next step was to conduct the exercise outdoors in an attempt to gain both the benefits of exercise and of being in the natural environment. The range of activities that green exercise typically covers are walking, running and hiking. Some studies indicate that exercise in the natural environment can cause reduction in blood pressure and improve self-esteem (Pretty et al., 2005; Pretty et al., 2007). The research in this area is however in its infancy and further work is required to demonstrate the full benefits. 


\section{Wilderness Therapy}

Wilderness therapy is defined by Davis-Berman and Berman (1994:13) as "the use of traditional therapy techniques, especially for group therapy, in an out-of-doors setting, utilising outdoor adventure pursuits and other activities to enhance personal growth". The target audience for this therapy is however much more specific than for green exercise. Wilderness therapy is used primarily to combat emotional, psychological and addiction problems of young adults (Hobbs and Shelton, 1972; Bandoroff, 1989; Russell, 1999; Russell and Phillips-Miller, 2002; Caulkins et al., 2006; Russell, 2006a; Bettmann, 2007). The motivation behind wilderness theory is to isolate the individual from the normal social space in which they have created routines that cause ill-health (Cumes, 1998). The wilderness not only creates the time for reflection, but also interpersonal development, as group work is a key theme in this therapy, and both aim to prevent the return to former harmful personal routines (Hans, 2000; Wilson and Lipsey, 2000; Russell and Phillips-Miller, 2002; Russell, 2006b). As such, wilderness therapy can be used to treat substance abuse (Bennett et al., 1998) and mental health problems (Crisp and O’Donnell, 1998; Beringer and Martin, 2003) in particular. Further to these examples of green and blue gym services, the specific cases studies and the provisions that exist within them will be explained in the next section.

\section{CASE STUDIES}

In order to explore and contrast the different business practises that determine the success or failure of environmental human health organisations two European case studies were chosen. The sites were selected on the number of organisations present, and how developed their network was in terms of size, density, connectivity and diversity of services on offer. The case studies represented highly evolved service provisions, which covered public, private and third sector organisations. As the Nordic countries are at the leading edge of these types of public health interventions, Finland was chosen as the site against which to model the UK sector.

Despite having all of these facets in common, both sites exhibited significant differences as well. The case study in Cornwall represented a highly dense collection of organisations and environment types on a local or regional level. Finland, because of its dispersed population centres has services spread out across the nation. Institutionally, Finland also had professional organisations such as Green Care Finland that co-ordinated standards, training and network opportunities. Similar formalised bodies did not exist in the Cornish case at the time of the study, only informal networks. Hence, the density of service, but also the institutional backing for such organisation varied between cases. It was felt that the mix of similarity but also differences between the cases provided a solid basis for determining how environmental human health organisations function from a service delivery perspective.

\section{Cornwall - Blue and Green Gyms}

The Green Gym concept was pioneered by the British Trust for Conservation Volunteers (BTCV) in 1997, when they stated to advertise their conservation volunteer opportunities as a means to improve physical health (Birch 2005). From this the BTCV (now renamed TCV) rolled out the programme across the UK (Reynolds, 2002), and many other conservation and nature-based organisations followed suit with similar initiatives, positioning the environment as a health and well-being resource. Diversifying the activities to areas that might also improve one's physical fitness: horticulture, animal husbandry, hiking, downhill skateboarding etc. (Pretty et al., 2007) The concept in its current state then promotes both the physical and mental benefits of outdoor exercise (Lister et al., 2017), and has come to be associated with the more generic term Green Space. Its sister concept, the Blue Gym, is simply the same concept applied to different types of marine environments (White et al., 2016).

Cornwall is home to a number of interventions that build on the concept of the 'Blue Gym' (Depledge and Bird, 2009). The Blue Gym works on the well-established principle of the restorative properties of nature, both mentally and physically (Kaplan and Talbot, 1983; Kaplan and Kaplan, 1989); namely through engagement with the natural environment and in particular areas near water to improve public health and well-being. The restorative effects of blue space in particular has also been documented by White et al. (2010), Ashbullby et al. (2013), Wheeler et al. (2012). As such, the Blue Gym aims to:

\footnotetext{
"specifically promote mental and physical health benefits of participation in exercise along healthy coasts and in related aquatic environments. The sea and inland waterways offer a large health resource that has yet to be explored fully" (Depledge and Bird, 2009: 948)
}

Cornwall has a diverse mixture of ecosystems, providing different ecosystem services, these include access to the Celtic Sea and English Channel, reservoirs, farmland, moorland, national parks and islands (Bowen et al., 2014). This has led to a clustering of ecological services that are related to the sea and water-based activities as well as inland 'green' activities. This density of ecosystem services related to both Blue and Green gym organisations was one of the criteria for selecting it as a case study. 


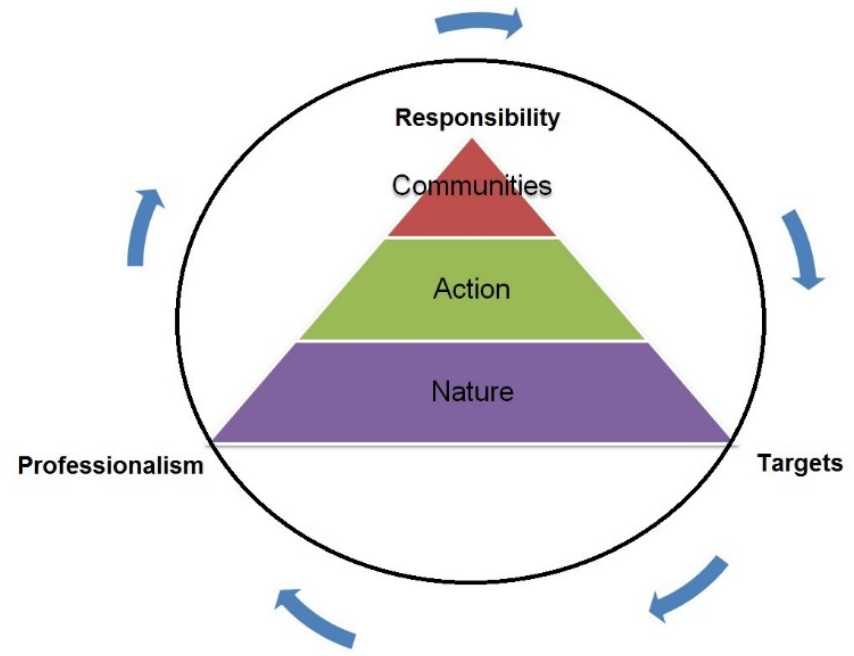

Figure 1. Green Care a diagrammatic explanation adapted from (Green Care Finland, 2013)

\section{The Green Gym in Finland - Green Care}

In a similar vein to the Green Gym in the UK, the concept of Green Care has been developed in Finland (Soini, 2012). This has been facilitated within an organisational network known as Green Care Finland. According to Sempik et al. (2010: 11) "Green care is an inclusive term for many 'complex interventions' such as care farming, animal-assisted therapy, therapeutic horticulture and others." This interaction from a service perspective is shown in Figure 1 where the triadic relationship between nature, action and communities is delivered through the mechanisms of responsibility, target setting and professionalism. Sempik et al. (2010:11) suggest that the linking factor between the interventions is "their use of nature and the natural environment as a framework in which to create these approaches." This form of therapy whilst rooted in nature does not have to happen in a wilderness. It can function in the grounds of nursing homes, prisons or hospitals (Haubenhofer et al., 2010). The exact type of therapies that are utilised varies across European nations, with some having far greater prevalence in one area for example horticultural therapy in the UK (Sempik and Aldridge, 2006), care farming in the Netherlands (Hassink et al., 2014) and equine assisted therapy in Finland (Hassink and van Dijk, 2006). In Finland the sector is something of an umbrella concept that has existed for many years but has only recently come under one heading, that of Green Care. It should be stated that the sector it is still in it's infancy, something Soini (2012:13) described as "moving from novelty to niche" in regard to its development. Due to this framework's similarities to the use of natural environments to promote public health and well-being it forms the basis for a comparative international study against the data collected in the UK.

Whilst the literature available in English on the subject of Green Care is still in development, it includes a conceptual framework for green care (Sempik et al., 2010; Braastad et al., 2007; Berget et al., 2012). There has also been a review of green care in the Nordic countries (Steigen et al., 2015), an international comparison of green care practices within farming (Partanen et al., 2006), an investigation of the historical developments of green care in Europe (Haubenhofer et al., 2010), and a study on the role of green care in sustainable education (Risku-Norja and Yli-Viikari, 2008).

In Finland Green Care is based on three pillars, namely nature, action and communities (see Figure 1). Public health and well-being effects become visible by combining and emphasising these elements is various ways. Nature is the place of action, target or a tool and animals one central element of nature. Action links people with environments and create possibilities for the experiences and learning. Community allows partnership either with people or with animals, nature or a certain place (Green Care Finland, 2010).

The foremost organisation to promote this concept in the country is Green Care Finland, which was established in 2010. It is a network of agricultural based therapy sites in 60 locations throughout Finland (Green Care Finland, 2014). Its activities include eco-psychology through farm work, animal assisted therapy, predominantly horses (hippotherapy) but also cats, dogs and sheep; garden assisted therapy and adventure education for tourists and those in social care schemes. These activities are targeted at stress cases, drug rehabilitation, and social work and to a lesser extent schoolchildren and tourists. The programme is similar to the Green and Blue Gym in the UK. Finland was chosen as a host nation as it has a highly developed public health and well-being industry but also has a population with high-levels of English fluency.

Finland despite all its fluvial environments did not at the time of the study have as many blue gym organisations as Cornwall. The Finland case studies were spread out over a much larger territory than the Cornwall Case study - but when you consider the relative population densities this is not particularly surprising. 
Table 1. Interviewee characteristics from entrepreneurs in Cornwall

\begin{tabular}{|c|c|c|c|c|c|}
\hline Number & Sector & Location & Number of Staff & Status & Target Audience \\
\hline 1 & Surf experience & West Cornwall & $\begin{array}{l}1 \text { full time } \\
2 \text { part time }\end{array}$ & CIC & Primary and secondary schools, NEETs* \\
\hline 2 & Sailing experience & South Cornwall & 5 full time & Charity & $\begin{array}{l}\text { Drug rehabilitation, young offenders, } \\
\text { learning difficulties, NEETs* }\end{array}$ \\
\hline$\overline{3}$ & Adventure Sports & South Cornwall & $\begin{array}{l}7 \text { full time } \\
4 \text { part time }\end{array}$ & $\begin{array}{l}\text { Private business } \\
\text { and CIC }\end{array}$ & $\begin{array}{l}\text { Young offenders, stag and hen parties, } \\
\text { military veterans, wheelchair bound } \\
\text { NEETS* }\end{array}$ \\
\hline 4 & $\begin{array}{l}\text { Obesity reduction } \\
\text { activities in church } \\
\text { affiliated organisation, }\end{array}$ & Mid Cornwall & 3 full time & Charity & Families with obese children \\
\hline 5 & Nature conservation & West Cornwall & $\begin{array}{l}6 \text { full time } \\
5-10 \text { volunteers }\end{array}$ & Charity & $\begin{array}{l}\text { Children and adults with Learning } \\
\text { difficulties, senior citizens, students }\end{array}$ \\
\hline 6 & Eco-hotel & Mid Cornwall & 27 full time & Private business & Sustainability minded tourists \\
\hline$\overline{7}$ & Walking Activity & West Cornwall & 5 full time & Private business & Families, young children, disabled \\
\hline 8 & Oncology massage & West Cornwall & $\begin{array}{l}4 \text { full time } \\
7 \text { part time }\end{array}$ & $\begin{array}{l}\text { Private business } \\
\text { and Charity }\end{array}$ & $\begin{array}{l}\text { Breast cancer patients, testicular cancer } \\
\text { patients, people in remission }\end{array}$ \\
\hline$\overline{9}$ & Sailing adventure & South Cornwall & $\begin{array}{l}1 \text { full time, also a } \\
\text { number of volunteers }\end{array}$ & Charity & Adult offenders \\
\hline$\overline{10}$ & Kayaking adventure & West Cornwall & 2 full time & Private business & Students and tourists \\
\hline
\end{tabular}

*Not in Education, Employment or Training

Table 2. Academic interviewee characteristics

\begin{tabular}{lllll}
\hline Number & Institution & Location & Sector & Specific Focus \\
\hline $\mathbf{1}$ & University of Akureyri & Iceland & Natural Environment based Tourism & Nordic well-being and wellness \\
\hline $\mathbf{2}$ & University College Dublin & $\begin{array}{l}\text { Republic of Natural Environment based Tourism } \\
\text { Ireland }\end{array}$ & Environmental resource use \\
\hline $\mathbf{3}$ & Lund University & Sweden & Natural Environment based Tourism & Sustainable Tourism \\
\hline $\mathbf{5}$ & University of Exeter & England & Natural Environment based Tourism & Service design and innovation \\
\hline $\mathbf{6}$ & University of Lisbon & Portugal & Natural Environment based Tourism & Services for the retired and senior persons \\
\hline $\mathbf{7}$ & $\begin{array}{l}\text { IUBH School of Business and } \\
\text { Management Berlin }\end{array}$ & Germany & Natural Environment based Tourism & Sustainability in food use \\
\hline $\mathbf{8}$ & $\begin{array}{l}\text { Corvinus University of } \\
\text { Budapest }\end{array}$ & Hungary & $\begin{array}{l}\text { Spas and natural environment based } \\
\text { Tniversity of Eastern Finland }\end{array}$ & Spiritual used of natural sites \\
\hline
\end{tabular}

\section{METHODS}

\section{Selection Criteria}

Recruitment of participants was based around convenience sampling (Etikan et al., 2016) drawing from our existing network of organisations within the environment and human health sector. In Cornwall, invitations were sent to businesses operating in the Blue and Green Gym sectors, based on networks developed at the European Centre for Environment and Human Health, in the University of Exeter. In Finland, invitations were sent to fortyeight businesses in the Green Care Finland Network. Further interviews were conducted with academics as part of the COST Action TObeWELL22.

The length of study and number of participants is driven by the criteria of exhaustiveness (Benzécri, 1973; Le Roux and Rouanet, 2010). The questions used in the interview schedules were formed from barriers to innovation literature as well as specific suggestions by innovation experts (IBM, 2006; Wuppertal et al., 2009; Arundel and Kemp, 2009; Bessant, 2012; Owen, 2012). In addition, the questions were designed to promote thick description (Geertz, 1973). From the thematic analysis, representative quotations were used to illustrate the themes, which are given in section 5.0 .

\section{Organisations}

Eighteen organisations participated in the first study, totalling ten entrepreneurs (see Table 1) and eight academics (see Table 2). From the organisations interviewed, three used Green Gym health interventions, three used Blue Gym interventions, and one used a mixture of Blue Gym and Green Gym schemes. In addition, there was an eco-hotel, and a kayaking adventure service, that used outdoor services. By sector, there were five registered 
European Journal of Environment and Public Health, 2(2), 08

Table 3. Green Care Entrepreneurs Interviewed

\begin{tabular}{|c|c|c|c|c|}
\hline Number & Sector & Location & Number of Staff & Status \\
\hline 1 & Gardening therapy for seniors, & Helsinki & 34 & Private Business \\
\hline 2 & Care farming and animal husbandry, & Central Finland & 3 & Charity \\
\hline 3 & Equine therapy, & Helsinki & 3 & Private Business \\
\hline 4 & Out-door well-being development, & Lapland & 1 & Private Business \\
\hline 5 & Care farming and animal husbandry, & South-West Finland & 2 & Charity \\
\hline 6 & Equine therapy for children, & Central Finland & 3 & Church based Charity \\
\hline 7 & Equine and farm therapy for foster children (girls), & Western Finland & 6 & Charity \\
\hline 8 & Green Care for Dementia patients, & Central Finland & 14 & Private business \\
\hline
\end{tabular}

Table 4. Academics Interviewed in Finland

\begin{tabular}{lll}
\hline Number & Research Area & Organisation \\
\hline $\mathbf{1}$ & Cultural policy & University of Jyväskylä \\
\hline $\mathbf{2}$ & Biology department (botany) & University of Helsinki \\
\hline $\mathbf{3}$ & Forestry economics & University of Helsinki \\
\hline $\mathbf{4}$ & Biology & University of Eastern Finland \\
\hline
\end{tabular}

charities in the study, five private businesses and two Community Interest Companies (CIC). The predominant business model was micro-businesses; however, it would also be possible to classify four of the organisations as family businesses. Five of the organisations used part time staff and volunteers. The private businesses and the nature conservation organisation (which is part of a UK network) expand their staff levels in the summer to cater to consumer demand. Equally, those who used volunteers attracted more of them in the summer months.

\section{Academics}

In addition to the organisations listed in Table 1 academics from Finland, Germany, Hungary, Iceland, Ireland, Norway, Portugal, Sweden, and the UK and were interviewed, the details of which are shown in Table 2. The academics all are natural environment and health related researchers who were interviewed to compliment the lay organisational perspective.

\section{Finland}

Eight Green Care organisations participated in the Finnish study. The interviewees covered a broad geographical spread and had a variety of target audiences and services. In an effort to establish the breadth and depth of the Green Care field, the interviewees were asked to describe all the target groups and conditions that they work with. These included medical issues such as: drug rehabilitation, people in supported housing, foster homes, homelessness, and mental disabilities of various types but mainly with senior citizens, but also corporate training, and school clubs involving animals. The Green Care providers that participated in the study are given in Table 3.

Consistent with the first case study five academics with a knowledge or involvement in Green Care processes were interviewed to get a balance between lay and expert opinion. A description of the academic interviewee's is given in Table 4. In total thirteen interviews were conducted, further details of the methodology used are given in the next section.

\section{Interview Method}

For the data collection in Cornwall and Finland we drew upon an ethnographic interviewing methodology. The concept is a mixture of techniques, which is largely concerned with reflexivity, the co-creation of research and ethnographic approaches (Heyl, 2001: 369). Heyl (2001) went on to summarise the approach by synthesizing the two seminal works of Eisner and Peshkin (1990) and Kvale and Brinkman (2009) into a four point methodology for ethnographic interviewing:

1. "Listen well and respectfully, developing an ethical engagement with the participants at all stages of the project

2. Acquire a self-awareness of our role in the co-construction of meaning during the interview process;

3. Be cognizant of the ways in which both the on-going relationship and the broader social context affect the participants, the interview process, and the project outcomes; and

4. Recognize that dialogue is discovered and only partial knowledge will ever be obtained."

Working with green or blue space organisations and their patients in an ethnographic manner, often involves discussions of sensitive medical topics or conditions. It was felt that a methodological approach rooted in reflexivity and respectful listening was the most appropriate choice given the topic under investigation. As with any ethnographic work, there is a significant amount of preparation that occurs prior to the interviews themselves. 
Transcript of interview 001

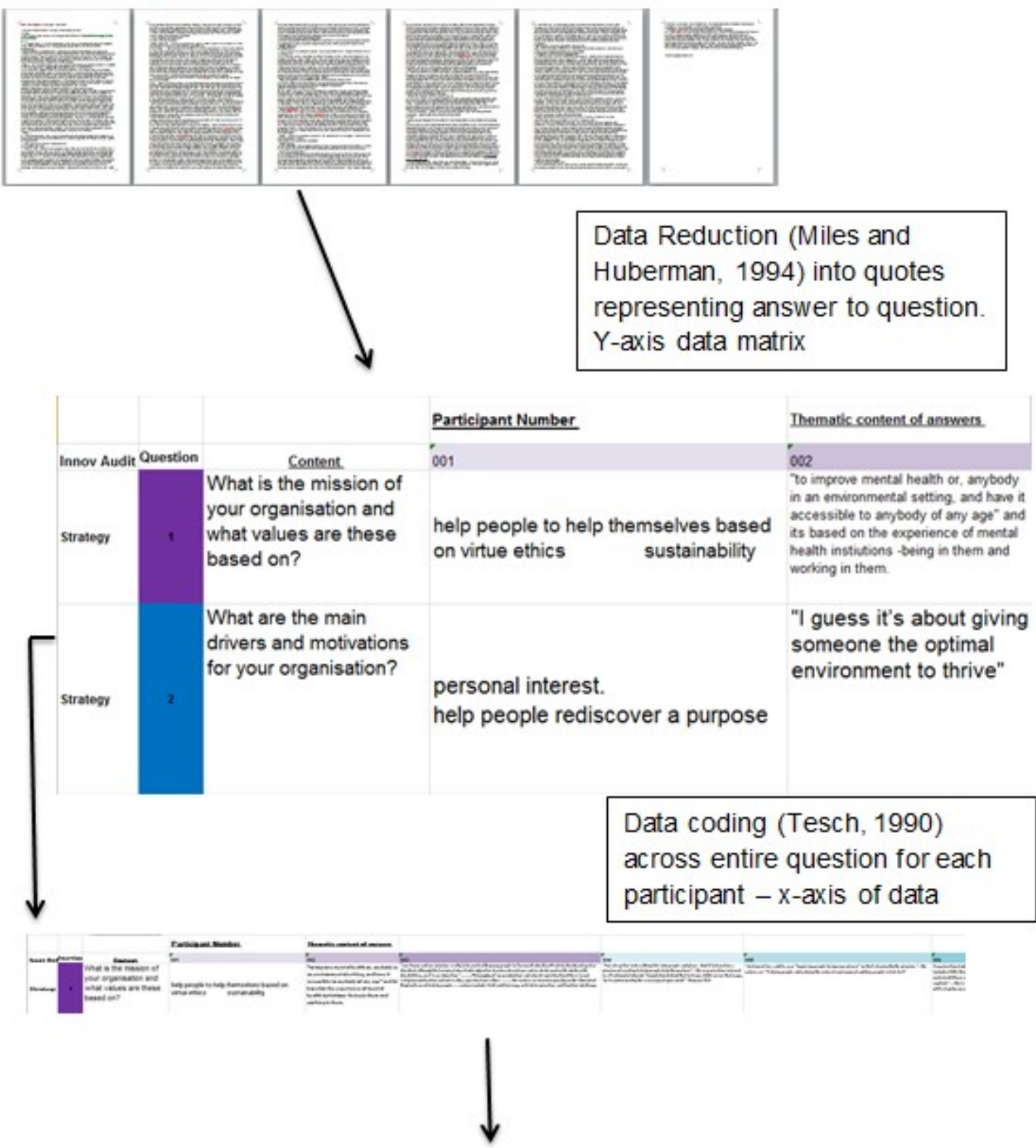

\section{Themes for Question 1}

Figure 2. Interview analysis flow diagram

This covers not just learning the skills to analyse the interviews but also collecting data that allows the researcher to comprehend and socially place the nature of the company/manager under question.

\section{Data Analysis Methodology}

The qualitative data that was generated from the interviews was thematically analysed through two processes know as data reduction (Miles and Huberman, 1994) and data coding (Tesch, 1990) to produce a qualitative data matrix, see Figure 2. Data reduction is "a form of analysis that sharpens, sorts, focuses and discards, and organizes data in such a way that 'final' conclusions can be drawn and verified" (Miles and Huberman, 1994:11). Similarly, the function of data coding is "to aggregate all data about the same topic or theme, so that each category can be studied individually" (Tesch, 1990: 101). The data matrix is a compressed assembly of the transcript information that allows inferences to be drawn (Miles and Huberman, 1994; Nadin and Cassell, 2004). A graphic representation of this process if shown in Figure 2.

This process of data analysis permitted the researcher to distil down the interview transcripts into thematic innovation categories, such as strategy. Whilst also organically allowing new themes to emerge from the data itself. 


\section{RESULTS}

This section presents the main findings of the study, collected under a number of broad thematic categories. Participants discussed a range of issues, ranging from the history of their health and well-being interventions to how the particular interventions addressed public health and well-being issues.

\section{The History of Green Care and Ecological Public Health}

In the current era, the emergence of using nature as a public health and well-being resource is well documented in the seminal work of Brown and Bell (2007); tracing the history of the medicalisation of nature in the UK. No such work yet exists for tracing the history of Green Care in Finland. When asked about the emergence of Green Care most organisations said that it started between 2004 and 2008 but that similar services (including their own) had been running for at least 20 years. One interviewee showed a researcher a book on the subject from the $1920 \mathrm{~s}$ that was part of her education in equine pedagogy. In addition, a comment by one of the interviewees is illuminating in showing Finland's particular strength in socio-pedagogic activities with animals:

"V Riding therapy has its origin in Finland in 1970-1980's. Socio-pedagogic horse activities in 1990's. Seikekailukasvatus (outdoor education) in 1990's. Horticultural therapy is the oldest field. Some psychiatric units with large gardens have been built in the beginning of 1900's. Also horticultural therapy has been refound [sic] during the recent decades. The concept of "Green Care" was introduced for Finnish discussions in 1996 by MTT Agrifood Research Finland."

In both the Cornwall and Finland there is a diverse array of applications of environmental health services, as will be shown in the following sections.

\section{Assessment of Demand for Services}

The construction of demand for Green Care services takes a very specific form as they are almost entirely contracted by municipal care departments e.g. local government. In addition, there is an existing subsidy scheme for some forms of care, in specific cases, the subsidies are mandatory. This context is very far removed from the UK situation, as such, the innovativeness in demand forecasting due to the state-based Finnish care system is low. This was well encapsulated by a professor:

"L I think that most entrepreneurs that are in the field are... doing this and not through any systematic way, they, they have just started, maybe, the activity in a very small scale"

It was suggested that the most common method was simply to benchmark what other organisations where doing to understand demand from different sectors. Another professor remarked that:

"D some are more professional but anyway this sector is very heterogeneous, the skills are, ah, many don't have, ah, business or tourism education so they have just come into the field"

This highlights the only sector that forecasts demand and uses demographics to influence its direction is the tourist industry, which offers nature services with some basic therapeutic value. This was a reoccurring theme within the data, however, not all tourist organisations interviewed could be said to have this level of innovation management.

\section{The Role of Nature in Health and Well-being Services}

Given that health care provisions exist and are readily available for the sectors mentioned (obesity, depression, substance abuse etc.), the researchers asked the participants why they wished to create a new service based around the use of nature. The answer becomes key to explaining the raison d'etre of the rest of the service activity. The explanation encompasses many sequential steps as to why nature is needed. The process is explained in brief below and then specific examples of each step will be given:

i. Services are specifically designed for individuals' needs

ii. These services are based around routine behaviours of that individual and their personal and social habits

iii. This is done to create a process of normalisation that relates back to a former state of health prior to the person becoming ill e.g. not depressed, without dementia or a drug addiction etc.

iv. These routines generally function at a habitual level if they are to be of use on a daily basis, e.g. we are not conscious of all of our actions all the time

v. As such nature is used to embed these new routines because it allows access to the latent forms of thought not ones that require direct conscious learning e.g. as is suggested in Biophilia (Wilson, 1986; Kellert and Wilson, 1995) or Attention Restoration Theory (Kaplan, 1995)

\section{Service Specificity}

Service specificity was found in both Finland and in the UK. The theme become manifest in multiple ways. Firstly, the observation that due to the primarily mental nature of the conditions observed, health becomes a set 
of progressive and emerging states. That is to say, ones' depression, addiction or level of dementia can both oscillate between improvements and regressions but also have a linear improvement or decline. As such observing phenomenon over time means that treatment of those phenomenon is specific to the stage that it is currently in. This is described by one of the research participants in Finland:

" $\mathrm{T}$ Yeah, and of course people who are in care, they are sometimes very passive and they have lost their belief in their ability to do things so this is a challenge for us, to build it gradually so that they get this strength back again and they start believing that they are able to do something and it's good to enjoy. Of course we have a lot of challenging customers. But it is interesting at the same time."

The last sentence does highlight that the service is not all about challenge, but that it introduces some variability in the activities conducted by the provider, helping to avoid monotonous repetitive work. This concept was further elaborated upon by the same participant:

"Researcher: So do you match the kind of level that the customer is at to what the activity you are going to give them, or the environment that you put them in?

$\mathrm{T} \quad$ Oh yes. And we are making kind of practical papers about our activities, what you can do, what implements you need, how much does it cost, and there is always a few lines about what ability is demanded for people who are attending so we have to look at it very carefully.

"Researcher: Do you consider just the physical ability or is it going to be the mental ability as well?

$\mathrm{T} \quad$ We look at both because many people they have also like learning disabilities so we try to adapt for that as well."

This illustrates a practice that was continually found in services. That the condition of the client is both monitored in paper form and then the activities directed toward that client are shaped around the specifics of that condition. This includes both the physical and mental ability of the client and as observed previously the exact state at which their condition is in. This was the closest behaviour that the researcher found to systematic monitoring by the service providers. This adaptivity in the service is also mediated through the relationships the clients have with the service providers. To conduct a wide range of activities that are fluctuating sometimes on a daily basis requires a certain level of trust:

“Researcher OK, so it's like you have to be adaptive to what you've got.

$\mathrm{T} \quad$...you know the people and they know you and you build the trust between you gradually when you meeting those people. For example, last year we had a one activity when we tried to get people from a family addiction treatment place and somebody had said that yes, they wanted to go fishing and we have fishing people and we arranged the day when they go out by boat and so but when the day came and it was all arranged, nobody came out because they didn't know the leader."

This is a point addressed by Bourdieu, when he suggested that time invested in relationships and activities functions as a proxy for social capital (Bourdieu, 1980; Bourdieu, 1979), something that he terms lex insita, the law of graft that underpins the formation of the social world. In the case of Cornwall, this specificity related not just to the disease condition but also the natural environment. There was a high frequency of the use of natural environments to mimic mental states e.g. matching a natural environment type to a particular cognitive behavioural therapy practise. The diversity of the natural world offers a highly flexible service, especially in locations that have many types of coastal and inland environments. For example, to break the therapy into two simplistic groups, there are meditative and active therapies. For the meditative or mindfulness exercises, organisations would pick sheltered bays, river inlets, reservoirs or streams with less turbulence. For the positive challenge and active sessions, the organisations would choose open seas or the mouth of an estuary with more turbulent and challenging conditions. For example:

"V the analogy with the sea with the tide, with the seasons with the swells it distils right down to that, so you have your flat calm days where there is hardly a ripple, to the turbulent on-shore storm force 10 , $20 \mathrm{ft}$, wild, woolly and completely, and that sits with the different mind states that everyone goes through. Everyone has cycles, everyone has their own rhythms and I think that transposes into the outdoor and all of our activities"

These mental states are not limited to a singular individual either. There are examples that cover family based obesity programmes to engender changes within that unit. These environments have to be both challenging but also reflective of both the adults' and child's needs. What made this process fluid was the existence of varying types of environments within 30 minutes' drive of any location within Cornwall. If a different treatment or group needed access to another type of therapy all that was required was to relocate at the expense of only a short period of time. The reason that this level of specificity is possible is due to the fact that constantly changing environments provides a means to be flexible with the service activity chosen: mindfulness etc. The rhythms in nature on a daily and seasonal basis gives the opportunity for services providers to be flexible with the activities they offer. In addition to the natural changes to an environment, it can also be physically altered to suit a particular condition. 
"M We can be quite ruthless here and just use it [the natural environment] as a tool, and our key tool is the outdoors and the environment that we have got here, and it's adapted, we will twist it to suit whatever the nature of the group is be it, on the edge of the quarry having a counselling session counting butterflies or literally flying head first off the cliff face"

This quote helps to extend our developing concept. That is to say, it is not just the variation of natural environment types that allows one to match them to mental states, but also the fact that nature is in a constant state of Heraclitian flux. With seasonal and daily changes in weather, tides etc. moreover this change can be manipulated or selected depending on the client's needs.

\section{Routines}

The second theme in our process points to the fact that services are based around routine behaviours of individuals and their personal and social habits. Specific conditions of a natural environment and health state are used to create routines for the service users. This has the functions mentioned previously i.e. nature is in a state of constant alterity yet also seasonally-fixed, which allows for multiple permutations that can fit the specific daily needs of a client's particular disease and the particular state that a disease currently manifests. The passing of time causes alterations in seasons that form the basis of routines, for example in a case from Finland:

"T Yes, which goes around the year and we are building activities week by week which you can use like if you are in March, what kind of gardening activities you can do in the first week of March, or what you can do in fishing in March and there are practical notes for that and we are fielding this calendar all the time so I varies and I think this is also important, that when it changed according to the time, customers also get a taste of changing seasons and activities and so this is very important for many people, that you are living the seasons and the changing activities, what you have to do in September and so on."

The process of routine creation helps to bond the participant and the carer as well as being a mechanism for innovation. Nature provides, it would seem, the most diverse and accessible option to do this. Interviewees noted as well that is it key to balance the level of challenge with safety:

"M Yeah, yeah, part of the experiential learning is always to have a challenge that's, that

is, uh, the right size for your skills but to have a challenge, to accept, to take on that challenge you need to feel safe enough."

The use of phrases such as "the right size for your skill" illustrate the specific nature of actions with Green Care health interventions. Beyond the concept of challenge, which the service providers utilised it was regularly argued that nature's role was also to teach empathy to participants. This is perhaps a more specifically Finnish phenomenon due to the prevalence of equine and animal assisted therapies that exist in Finland:

"T1 Also, I think that, that, for example, the health of animals is one very big thing...is that we see them born and we get to see them die too so it's like a circle of life. seeing and when we've lost some of our horses or dogs or something like that, it's always a valuable place to learn how to handle with grief, because it's, it's terrible when animal dies and it's terrible for us too and we show how our process, how...

$\mathrm{K}$ our feelings

T1 we process our grief, so they can learn from us and they are allowed to grieve and be sad and mad and, and miss the ones that die, and it's really, really, really terrible to say but it's really a good place to practice grieving because we all have to face some grief in our lives, it's going to be part of our life at some point, our parents die or our relatives die or our spouses die"

This process was also echoed by a professor interviewed, whose work mainly centred on Green Care therapies in prisons. In an attempt to teach empathy through the life and death cycle, a prison in Helsinki keeps sheep and chickens that the inmates husband until the animal's death. This mimics the process explained in the quote above, but is delivered under the auspices of a state authority.

\section{Normalisation}

Drawing on the previous section, one can see that the creation of routines helps to normalise a person's activities when they are ill. For example, illness creates a change in habit and action but the memory of pre-existing states of health is still present in all but the most severe forms of mental illness. I.e. it is possible for service users to conceive of what it is not to be depressed or not addicted to drugs etc. normalisation and new routines, or a return to older routines can take many social forms e.g. dress, speech, daily activity schedule etc.

"T2 It's here for us [nature] to use and, and, er, I think that's one of the reasons that we use it but on the other hand we also see the difference between being in institution and being in a place like this where the nature is just open the door and you're in the nature so it gives some kind of normality." 
This point was made in regard to the basis for teaching by one respondent:

"M so, I realised then, after a couple of weeks, that I cannot teach these kids maths or physics or whatever unless I strengthened their social emotional skills first."

Normalisation is also the basis for many other theraputic procedures but until it occurs, further improvements cannot be made. Whether it is education, employment or even more simple forms of stability such as taking part in hobbies:

"T I think it was the idea which I mentioned, because like as we say 'normal' people, they are having all kind of hobbies and things which they are doing in the nature environment, like gardening and fishing and so I thought that the same thing should be possible for people who are in care because they need it even more than other people and still they don't always have this access to this although their need is even bigger than ours".

This also shows that the need of normality is perhaps greater for those who are without it, e.g. in a state of illness. One of the mechanisms for normalisation that was identified in the Cornish data set was leadership, which promoted autonomy for the services users in their daily structures:

"V I think challenge is probably, you know, if I had to distil it down to a word that would be one of the more appropriate ones for us...we use the term, positive challenge if someone is not happy we always reinforce that fact that they can just say I don't want to do it, we never ever force someone but the staff will do everything they can to encourage them, so if someone is afraid of height our ultimate aims to try and get them to abseil, so if they can abseil they have broken a massive barrier and everything else in their life might have a bit more perspective about it"

The natural environment is used in varying measures to promote leadership and confidence, as well as in a therapeutic fashion. This permitted the service providers to match the type of environment to particular groups' needs e.g. senior citizens, families, children, or corporate events. The concept of positive challenge is something that is closely related to an established depression treatment called behavioural activation (Jacobson et al., 2001) and so helps to create normalisation in routines and avoid listlessness.

\section{The Unconscious Process of Normalisation}

It was generally felt by the academics and service providers interviewed that the use of and being in nature helps to forge routines in unconscious parts of the mind. This is what allows them to be accessed on a daily habitual basis e.g. the client does not need to think consciously how to act; it becomes a mere process of unconscious habit.

"M Yes, yes, and as far as emotional and social, you know, sort of interactions, are concerned our brains aren't wired to constantly monitor the inner world of the other person."

This was perhaps one of the most frequently made points by both academics and those in the Green Care industry themselves. One participant neatly encapsulated the process as something that 'opens up our thoughts'.

"K I think, as we are in Finland, it has a very long history [of interaction with nature], yes, yes, and, but, what is crucial, I think, that we have used or have been interactive with nature unconsciously"

The process where the thoughts are opened up and the new routines are inscribed in the service users' mind is what makes the service in some ways so effective. It is designed so that the service users in many cases do not realise they are being treated. The reconstruction of prior states of health or memory of that state of health would seem a powerful tool to allow behavioural modification. This is not a new theme in itself for example de Bruin (2009) remarked on the construction of memory in dementia care services. As did Strandli (2007) in regard to Green Care dementia services in Norway.

\section{Religion and Public Health and Well-being Services}

Lastly, spirituality or religion played a role in most services that were interviewed; it either represented a set of values that drove the service aims or it was specifically rejected. One organisation provided therapeutic and sporting activities (obesity reduction) whose motivations for using the natural environment was a direct development of their faith. However, organisations founded by churches that had matured to a point where their income was no longer dependent upon the church, actively tried to distance themselves from religious association through name and constitutional changes etc. in fear of loss of funding and revenue. In other non-church based organisations spirituality seemed to play a latent role in public health and well-being services. Beyond this, there was a stark contrast in the role that spirituality played in different entrepreneur's organisations. There appeared to be three divisions of the use of nature and religion/spirituality.

\section{Judeo-Christian Use}

"M we do not promote ourselves as a faith organisation, it is a social enterprise but you asked for the drivers behind that and that certainly is our faith.... I think from our point of view it [nature] is a real connection with the creator of the universe. I guess because we recognise that and we think everybody else should have an opportunity to see it". 


\section{Eastern (Dharma and Animist) Use}

"E there is a lot to be learned in nature, from nature but also from eastern traditions."... "If you look at it [nature] properly, if you take the time to notice more details and things or anything really, how amazing it is. And really how insignificant we are, and how stupid we are"

\section{Darwinian Use}

"C I'm a Darwinist. I believe in evolution. Nature has evolved. We are part of that cycle anyway. We are animals and we evolve and we innovate so, yeah, I don't think you could separate them...The diversity of nature inspires me to innovate to get people to connect with those different aspects of nature. It inspires me, absolutely."

These three themes were echoed by the academics interviewed when questioned if there are common motivations or values for organisations innovating in the public health and well-being sector:

"L No, I don't [believe] that. I've usually considered these to be on a spectrum, if you like, going from what is discussed at purely medical services towards what can be considered being a new age, spiritual thing"

"P it seems to me that the message is slightly different depending on who you are talking to"

This illustrates that there is a broad spectrum of motivations and uses for the natural environment. So broad that both a Darwinist and a Christian entrepreneur are utilising the same broad conception of 'nature' for diametrically opposed reasons. Similarly, the concept of redefining the use of natural environments to make it appeal to another audience came out of the interviews:

"K I know from Vancouver Island as well they used to be fishing for salmon and now they're out just looking at whales, so it's almost like the idea of moving from one type of consumption to another type of consumption and consuming the natural resource to just visually consuming or smelling or experiencing it"

"L simply viewing the experience and visually experiencing natural phenomena of spectacular beauty, also of infinite dimensions of proportions etcetera, there are many ways to conceptualise this [nature]"

Both the academics and entrepreneurs interviewed showed a confluence of opinion over the multifunctional use of the natural environment, not just in the physical definition but also in an intangible sense. The major implications of this and others issues raised in section 5.0 will be considered in the following discussion.

\section{DISCUSSION}

The data from this paper can offer theoretical contributions towards the successful delivery of environmental public health services. We have outlined the basic individual mechanisms by which the natural environment is being used as a metaphor for mental processes, and how this draws upon habitual practises. This is because the natural environment is full of constantly changing systems, which provides a means to be flexible with the service activity chosen: mindfulness, positive challenge, CBT etc. It would seem from this that there is great potential due to the sheer diversity in the natural environment to operationalise these innovations both in the plethora of ecosystems and associated ecosystems services present and in how much they change on a daily, weekly, seasonal and annual basis. The natural environment is being positioned (Francis and Bessant, 2005) for health and wellbeing in a number of ways, interventions appear to be both individually, seasonally and location specific, but diverse in the ways they can be implemented. This approach by organisations represents a form of positional innovation, as defined by Tidd and Bessant (2009: 22), where a business targets its services and the story it tells about them to a new audience, without changing the physical product, but instead by positioning it in a new way, place or space. Based upon our data, an explanation of this process encompasses five sequential steps shown in Figure 3.

This set of five themes can become manifest in multiple ways, for example due to the primarily mental nature of the conditions observed, health becomes a set of progressive and emerging states. That is to say, ones' depression, addiction or level of dementia can both oscillate between improvements and regressions and have a linear improvement or decline. Observing such phenomena over time means that it is specific to its current stage. This includes services that can adapt for the day-to-day fluctuations in a person's mood as well as managing a longterm inevitable decline in such things as palliative care. Theoretically, the emerging habitual process that we have described bears similarity to what French sociologist Pierre Bourdieu called habitus. Bourdieu described the habitus as:

\footnotetext{
"a product of conditionings which tends to reproduce the objective logic of those conditions while transforming it. It's a kind of transforming machine that lead us to 'reproduce' the social conditions of our own production" (Bourdieu, 1993: 87).
} 


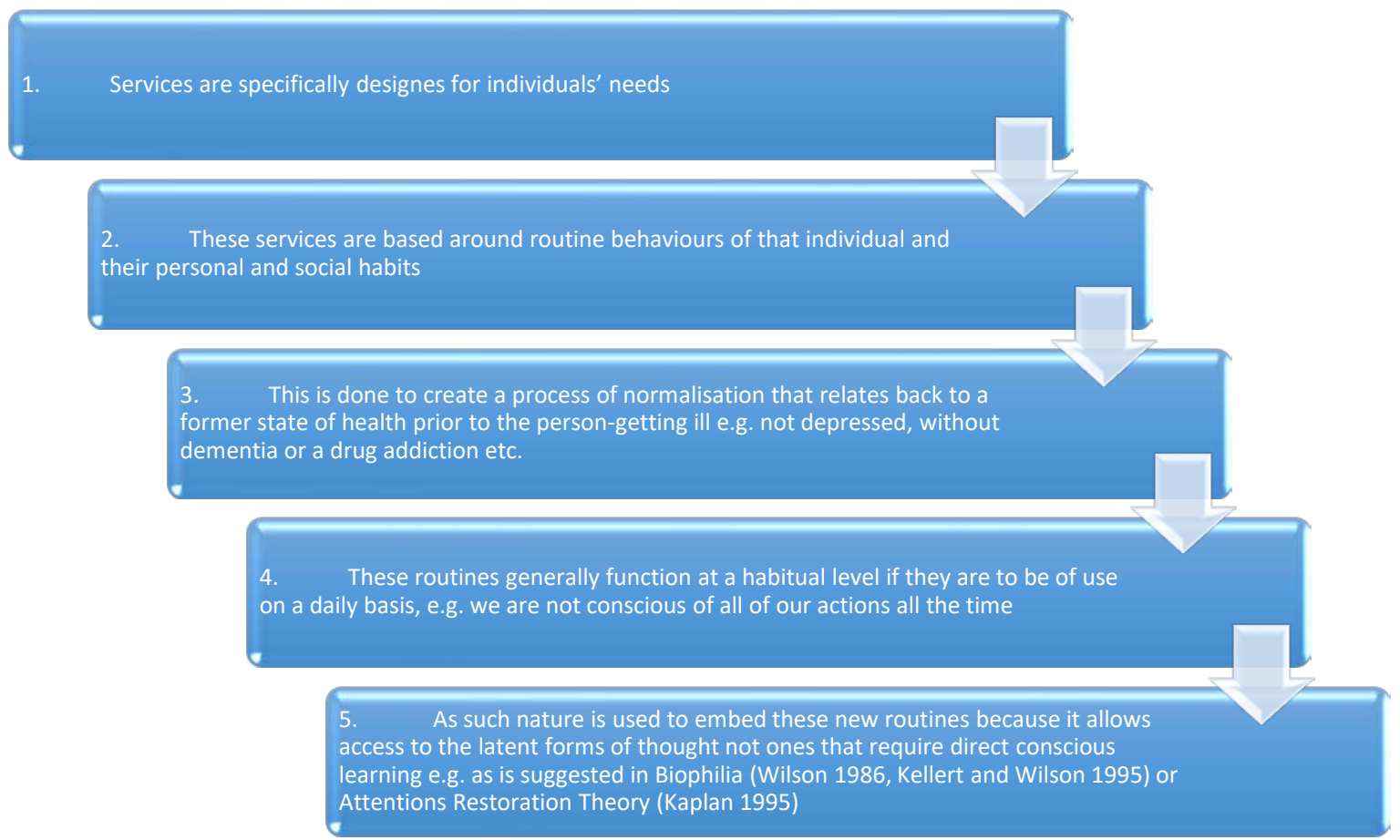

Figure 3. Interview Analysis Flow Diagram

The habitus is the 'generator', or 'organizer', of practices and representations of individuals. It operates in a person's recurring practices. Habitus is dynamic since it is updated incrementally and has a history (Bourdieu, 2000b). Habitus has two distinct parts, the first part is experiences from childhood (primary habitus), and the second part from our adult lives (secondary habitus). This is to state that one's collective social history iteratively comes to form a habitus. Some researchers such as Fuchs (2003) suggests the habitus can create the potential for social change. But it is also important to note that habitus is "in a sense, entirely arbitrary; there is nothing natural or essential about the values we hold, the desires we pursue, or the practices in which we engage" (Webb et al., 2002: 38). In addition, Bourdieu (2004) talked of L'babitus clivé - the cloven habitus, where a person's habitus is based upon "a reconciliation of opposites"3 (ibid: 130) to which he adds that the cloven habitus is "populated by tensions and contradictions" (ibid:127). The concept is then not to be taken as something solid and linear without internal conflict. In the same vein Bourdieu relates that 'habitus is one principle of production of practices among others and although it is undoubtedly more frequently in play than any other' (Bourdieu, 1990: 108). So habitus can be at times contradictory but also in specific actions and situations it is not present at all.

Research has been conducted by Bourdieu and others to evaluate the impact of habitus on the consumption of goods and services (Bourdieu, 2000a; Bourdieu and Wacquant, 1992; Fuchs, 2003; Vaughan, 2008). Habitus embodies a range of factors that affect behaviour: personal history, socioeconomic status, attitudes and indicators of social position (Bourdieu, 2000a; Bourdieu and Wacquant, 1992; Héran, 1987; Swedberg, 2011) similar to our findings. It is suggested that a persons is more likely to engage in a service if they share characteristics with their suppliers (Bourdieu, 2005). Similarly, Ozyilmaz and Berg (2004, 2009) identify the importance of employee habitus, and so involvement in the service sector in general. This was clearly apparent in our data where the service user and provider created a bond (share social capital) about the therapeutic value of nature when participating in activities. i.e. there clearly needed to be reciprocal level of trust in the relationship between patient and therapist (Pearson and Raeke, 2000).

Habitus then, both cloven and its original construction appears to bear significant similarity to the generative mechanism described by environmental public health business owners. Both concepts shared an idea of being individualistic, yet malleable, and subject to change in particular circumstances. One might suggest from a theoretical position that what is occurring in the five-stage process we have outlined is the progressive modification of the user's habitus, from illness to health.

The policy implications for those commissioning healthcare are that to create a successful service it must be designed specifically in relation to the stage a condition is in, with the possibility for being treated by multiple service provisions, dependent on the local ecosystems and ecosystem services and season. The service provisions is then simultaneously highly individualistic to person and place, but elastic in its delivery given the diversity of

\footnotetext{
3 Author's translation of « cet habitus clivé, produit d'une conciliation des opposés »

4 Author's translation of «l'habitus clivé, habité par les tensions et les contradictions. »
} 
natural systems that are on offer. Similar service models might be found in dementia reminiscence services (Woods et al., 2005) where services are highly individualised, but draw on significant events, such as royal wedding, the Moon-landing, etc. that were collectively experienced (Woods, 1998).

The results observed in Cornwall were homologous with the data collected in Finland where it was found that the innovations organisations carried out were basic and non-structured in most cases and close to what Williams et al. (1989), Ioannides and Petersen (2003) called "non-entrepreneurs". Whilst also displaying many hallmarks of lifestyle entrepreneurs (Ateljevic and Doorne, 2000), this being the emphasis of the non-economic objectives of an organisation that comes through the business development of hobbies and lifestyles. In this sense, the organisations interviewed in Finland have similarities to most European countries in the first study. Green Care is still in its infancy in Finland. The concept only really resurfaced around 2005, although it has deep historical and cultural roots (Brown and Bell, 2007). Opportunities for innovation in Green Care tourism in Finland are being driven by political and macro-economic forces; the global recession has caused the Finnish government to cut health care budgets (Rosendahl, 2013) and create market opportunities in healthcare (Christensen, 1997). Many Green Care organisations are looking to capitalize on this by increasing the level of contracts from the state health services. Most of the Green Care farms interviewed, whether they were designed for foster children, care homes or other target groups, provided external services to locals and to tourists. These primarily included equine therapy and other forms of animal assisted therapy whereas in the UK the focus is much more on horticultural therapy and social farming.

\section{LIMITATIONS}

This study had a number of limitations, primarily in relation to its design, and scope. Firstly, the work is based upon only two case studies in different nations, and is not exhaustive in this regard. To produce more generalizable conclusion outside of North Western European nations, more cases studies from different countries would be required.

Similarly, the cases used in this study, as a matter on contrast existed on different levels. I.e. one provided a national perspective (Finland) and the other regional (Cornwall). Depending upon the type of case study method employed, and the level of policy analysis required, case studies might have occurred at different, or similar levels of analysis.

Because of the limited number of cases, it was not possible to cover every aspect of Green Care or Blue Care that exists within Finland and Cornwall, but rather the study focused upon those that are more prevalent and accessible. Lastly, the study drew from ethnographic interviews, but a longitudinal business ethnography would provide deeper insights into green and blue space innovation practises. All of these points could be incorporated into future research on the subject.

\section{CONCLUSION}

The natural environment offers a number of benefits that can be exploited for public health and well-being and lessons can be taken in terms of new product development in this area for tourism companies. This could be done through the development of individualised services, which requires the service providers to have unique local environmental knowledge.

The inter-sectoral linkages between tourism, the environment and public health may be important to the sustainable development of societies in Europe in response to ageing populations and increased health care demands. A number of businesses that have not traditionally operated in the tourism and leisure space have moved towards mixed models of business - combining profit-making activities in the tourism and leisure markets with social action to ensure the sustainability of services in response to increasing pressures on funding sources. However, local and national authorities needs to do more toward encouraging innovation in the environmental public health sector, as many organisations were not innovative, nor concerned with the financial sustainability of their enterprises. Bespoke training courses for this sector in business improvement might go some way to resolving the issue.

\section{ACKNOWLEDGEMENTS}

This work was supported by investment from the European Regional Development Fund and the European Social Fund Convergence Programme for Cornwall and the Isles of Scilly. European Social Fund Division, part of the Department of Work and Pensions, is the managing authority for the European Social Fund (ESF) Convergence, which is one of the funds established by the European Commission to help local areas stimulate 
their economic development. ESF Convergence invests in the economic regeneration of Cornwall \& Isles of Scilly, investing in people, their jobs and skills. This research was also supported by the COST Action IS1204: Tourism, Wellbeing and Ecosystem Services (TObeWELL) Short Term Scientific Mission (STSM) fund. Thanks also needs to be given to Henna Konu, Katarina Boijer and Iiro Juola.

\section{REFERENCES}

Arundel, A. and Kemp, R. (2009). Measuring eco-innovation. United Nations University - UNU-MERIT Research Memorandum.

Ashbullby, K. J., Pahl, S., Webley, P. and White, M. P. (2013). The beach as a setting for families' health promotion: A qualitative study with parents and children living in coastal regions in Southwest England. Health \& Place, 23(0), 138-147. https:// doi.org/10.1016/j.healthplace.2013.06.005.

Ateljevic, I. and Doorne, S. (2000). Staying Within the Fence': Lifestyle Entrepreneurship in Tourism. Journal of Sustainable Tourism, 8(5), 378-392. https:/ / doi.org/10.1080/09669580008667374

Bandoroff, S. (1989). Wilderness-Adventure Therapy for Delinquent and Pre-Delinquent Youth: A Review of the Literature. University of South Carolina.

Beck, A. M. and Meyers, N. M. (1996). Health Enhancement and Companion Animal Ownership. Annual Review of Public Health, 17, 247-257. https:// doi.org/10.1146/annurev.pu.17.050196.001335

Bell, S. L., Wheeler, B. W. and Phoenix, C. (2017). Using Geonarratives to Explore the Diverse Temporalities of Therapeutic Landscapes: Perspectives from "Green" and "Blue" Settings. Annals of the American Association of Geographers, 107(1), 93-108. https://doi.org/10.1080/24694452.2016.1218269

Bennett, L. W., Cardone, S. and Jarczyk, J. (1998). Effects of a Therapeutic Camping Program on Addiction Recovery: The Algonquin Haymarket Relapse Prevention Program. Journal of Substance Abuse Treatment, 15(5), 469-474. https://doi.org/10.1016/S0740-5472(97)00222-5

Benzécri, J.-P. (1973). L'Analyse des Données. Vol. 1: La Taxinomie. Vol. 2: L'Analyse des Correspondances. Paris: Dunod.

Berget, B., Lidfors, L., Pálsdóttir, A. M., Soini, K. and Thodberg, K. (2012). Green Care in the Nordic countries a research field in progress. In HealthUMB, Norwegian University of Life Sciences. Trondheim: Nordic research workshop on Green Care in Trondheim.

Beringer, A. and Martin, P. (2003). On adventure therapy and the natural worlds: Respecting nature's healing. Journal of Adventure Education \& Outdoor Learning, 3(1), 29-39. https://doi.org/10.1080/14729670385200221

Bessant, J. (2012). Personal Communication. Truro, Cornwall.

Bettmann, J. (2007). Changes in Adolescent Attachment Relationships as a Response To Wilderness Treatment. Journal of the American Psychoanalytic Association, 55(1), 259-265. https://doi.org/10.1177/00030651070550010103

Birch, M. (2005). Cultivating Wildness: Three Conservation Volunteers' Experiences of Participation in the Green Gym Scheme. British Journal of Occupational Therapy, 68(6), 244-252. https://doi.org/10.1177/030802260506800602

Bird, W. (2007). Natural Thinking: Investigating the links between the Natural Environment, Biodiversity and Mental Health. Royal Society for the Protection of Birds.

Blake, W. (1998). The Illuminated Books of William Blake, Volume 5: Milton, A Poem: Milton - A Poem v. 5. Edited by Robert N. Essick. and Joseph Viscomi. Vol. 5. London: Princeton University Press; New Ed edition

Bloor, M. J., McKeganey, N. P. and Fonkert, J. D. (1988). One Foot in Eden: A Sociological Study of the Range of Therapeutic Community Practice. London: Routledge

Bourdieu, P. and Wacquant, L. (1992). Habitus illusio et rationalité. In Réponses: pour une anthropologie réflexive, 267. Paris: Seuil.

Bourdieu, P. (1979). Les trois états du capital culturel. Actes de la recherche en sciences sociales, 3-6. https://doi.org/10.3406/arss.1979.2654

Bourdieu, P. (2000a). Making the Economic Habitus: Algerian Workers Revisited. Ethnography, 1(1), 17-41. https://doi.org/10.1177/14661380022230624

Bourdieu, P. (2005). The Social Structures of the Economy. Translated by Chris Turner. Cambridge: Polity Press.

Bourdieu, P. (1980). Le capital social. Notes Provisoires. Actes de la recherche en sciences sociales, 31(1), 2-3. https://doi.org/citeulike-article-id:2764658

Bourdieu, P. (1990). In Other Words: Essays toward a Reflexive Sociology Malden, MA: Polity Press.

Bourdieu, P. (1993). Sociology in Question Theory, Culture \& Society: Sage Publications Ltd Original edition, Questions de sociologie.

Bourdieu, P. (2000b). Pascalian meditations. Cambridge: Polity Press.

Bourdieu, P. (2004). Esquisse pour une auto-analyse. Paris: Éditions Raisons d'agir.

Bowen, R. E., Depledge, M. H., Carlarne, C. P. and Fleming, L. E. (2014). Oceans and Human Health: Implications for Society and Wellbeing. Oxford: Wiley-Blackwell.

$16 / 23$

(C) 2018 by Author/s 
Braastad, B. O., Hauge, H., Koivunen, T., Rappe, E. and Korpela, E. (2007). Book of abstracts of the COST Action 866 conference. Green care in Agriculture: Health effects, Economics and Policies, Vienna, Austria 20-22 June 2007.

Breathnach, T. (2004). For Health and Pleasure: The Turkish Bath in Victorian Ireland. Victorian Literature and Cultureö 32(1), 159-175. https:// doi.org/10.1017/S1060150304000427

Brown, T. and Morag, B. (2007). Off the couch and on the move: Global public health and the medicalisation of nature. Social Science \& Medicine, 64(6), 1343-1354. http:// doi.org/10.1016/j.socscimed.2006.11.020

Bryder, L. (1992). A health resort for consumptives: Therapeutic landscapes and immigration to New Zealand, 1880-1914. Medical History, 40(4), 453-471. https://doi.org/10.1017/S002572730006169X

Caulkins, M. C., White, D. D. and Russell, K. C. (2006). The Role of Physical Exercise in Wilderness Therapy for Troubled Adolescent Women. Journal of Experiential Education, 29(1), 18-37. https://doi.org/10.1177/105382590602900104

Christensen, C. M. (1997). The Innovator's Dilemma: When New Technologies Cause Great Firms to Fail Edited by m. \& Van de Ven Tushman, A., The management of innovation and change. Boston, MA.: Harvard Business School Press.

Crisp, S. and O'Donnell, M. (1998). Wilderness-Adventure Therapy in Adolescent Mental Health. Australian Journal of Outdoor Education, 3(1). https:/ / doi.org/10.1007/BF03400677

Cumes, D. (1998). Inner passages, outer journeys: Wilderness, healing and the discovery of self. Minneapolis: Llewellyn Publications.

Davis-Berman, J. and Berman, D. (1994). Wilderness Therapy: Foundations, Theory and Research. in Beavercreek, OH: Kendall Hunt Pub Co (Accessed September 1994).

de Bruin, S. (2009). Sowing in the autumn season Exploring benefits of green care farms for dementia patients. Wageningen University, NL.

Depledge, M. H. and Bird, W. J. (2009). The Blue Gym: Health and wellbeing from our coasts. Marine Pollution Bulletin, 58(7), 947-948. https:// doi.org/10.1016/j.marpolbul.2009.04.019

Diaz, A. B. and Motta, R. (2008). The effects of an aerobic exercise program on posttraumatic stress disorder symptom severity in adolescents. International journal of emergency mental health, 10(1), 49-59.

DoH. (2004). At least five a week Evidence on the impact of physical activity and its relationship to health. Department of Health, Physical Activity, Health Improvement and Prevention.

Driver, F. (1988). Moral Geographies: Social Science and the Urban Environment in Mid-Nineteenth Century England. Transactions of the Institute of British Geographers, 13(3), 275-287. https://doi.org/10.2307/622991

Dunn, A. L., Trivedi, M. H., Kampert, J. B., Clark, C. G. and Chambliss, H. O. (2005). Exercise treatment for depression: Efficacy and dose response. American Journal of Preventive Medicine, 28(1), 1-8. https://doi.org/10.1016/j.amepre.2004.09.003

Eisner, E. W. and Peshkin, A. (1990). Qualitative Inquiry in Education: The Continuing Debate. New York: Teachers' College Press.

Etikan, I., Musa, S. A. and Alkassim, R. S. (2016). Comparison of Convenience Sampling and Purposive Sampling. American Journal of Theoretical and Applied Statistics, 5(1), 1-4. https://doi.org/10.11648/j.ajtas.20160501.11

Fine, A. H. (2006). Handbook on Animal-Assisted Therapy. Theoretical Foundations and Guidelines for Practice 2nd edition. 2nd ed. San Diego Academic Press.

Foley, R. (2014). The Roman-Irish Bath: Medical/health history as therapeutic assemblage. Social Science \& Medicine 106, 10-19. https://doi.org/10.1016/j.socscimed.2013.12.030

Forestry Commission. (2004). West Midlands Woodland \& Health Pilot Evaluation. Forestry Commission

Forestry Commission. (2006). Wye Wood evaluation. Forestry Commission. Available at: http:/ / www.forestry.gov.uk/fr/INFD-73QDK2 (Last Modified 2006, Accessed 09 January 2018)

Francis, D. and Bessant, J. (2005). Targeting innovation and implications for capability development. Technovation 25(3), 171-183. https:// doi.org/10.1016/j.technovation.2004.03.004

Frumkin, H. (2001). Beyond toxicity: Human health and the natural environment. American Journal of Preventive Medicine, 20(3), 234-240. https:/ / doi.org/10.1016/S0749-3797(00)00317-2

Fuchs, C. (2003). Some Implications of Pierre Bourdieu's Works for a Theory of Social Self Organization. European Journal of Social Theory, 6(4), 387-408. https://doi.org/10.1177/13684310030064002

Gaskell, S. M. (1980). Gardens for the Working Class: Victorian Practical Pleasure. Victorian Studies, 23(4), 479-501.

Geertz, C. (1973). Thick description: Toward an interpretive theory of culture. New York Basic Books.

Geores, M. E. (1998). Surviving on metaphor how "health = hot springs" created and sustained a town. In Putting Health into Place: Landscape, Identity and Well-being edited by Robin A. Kearns and W. M. Gesler, 36-52. Syracuse Syracuse University Press

Gerlach-Spriggs, N., Kaufman, R. E. and Warner, S. B. (2004). Restorative Gardens: The Healing Landscape. New Haven, CT: Yale University Press. 
Gesler, W. M. (1993). Therapeutic landscapes: theory and a case study of Epidauros, Greece. Environment and Planning D: Society and Space, 11(2), 171-189. https://doi.org/10.1068/d110171

Gesler, W. M. (1998). Bath's reputation as a healing place. In Putting Health into Place: Landscape, Identity and Wellbeing edited by Robin A. Kearns and W. M. Gesler, 17-35. Syracuse Syracuse University Press

Gesler, W. (1996). Lourdes: healing in a place of pilgrimage. Health \& Place, 2(2), 95-105. https://doi.org/10.1016/1353-8292(96)00004-4

Gonzalez, M. T., Hartig, T., Patil, G. G., Martinsen, E. W. and Kirkevold, M. (2009). Therapeutic Horticulture in Clinical Depression: A Prospective Study. Research and Theory for Nursing Practice, 23(4), 312-328. https:// doi.org/10.1891/1541-6577.23.4.312

Green Care Finland. (2010). Luonto byvinvoinnin lähteenä - suomalainen Green Care. Green Care Finland.

Green Care Finland. (2014). Green Care Finland. Available at: http://www.gcfinland.fi/eng (Last Modified 2014, Accessed 29 July 2018)

Growth Point. (1999). Your future starts here: practitioners determine the way ahead. Growth Point, 79, 4-5.

Hans, TracyA. (2000). A Meta-Analysis of the Effects of Adventure Programming on Locus of Control. Journal of Contemporary Psychotherapy, 30(1), 33-60. https://doi.org/10.1023/a:1003649031834

Hartig, T. and Marcus, C. C. (2006). Essay: Healing gardens? Places for nature in health care. The Lancet, 368, S36S37. https://doi.org/10.1016/S0140-6736(06)69920-0

Hassink, J. (2002). Combining Agricultural Production and Care for Persons with Disabilities: a New Role of Agriculture and Farm Animals. Wageningen: Wageningen University.

Hassink, J. and van Dijk, M. (2006). Farming for Healtb: Green-Care Farming Across Europe and the United States of America. Edited by R. J. Bogers. Dordrecht, The Netherlands: Springer. https://doi.org/10.1007/1-4020-45417

Hassink, J., Hulsink, W. and Grin, J. (2014). Farming with care: the evolution of care farming in the Netherlands. NJAS - Wageningen Journal of Life Sciences, 68, 1-11. https:// doi.org/10.1016/j.njas.2013.11.001

Haubenhofer, D. K., Elings, M., Hassink, J. and Hine, R. E. (2010). The Development of Green Care in Western European Countries. EXPLORE: The Journal of Science and Healing, 6(2), 106-111. https://doi.org/10.1016/j.explore.2009.12.002

Héran, F. (1987). La seconde nature de l'habitus. Tradition philosophique et sens commun dans le langage sociologique. Revue française de sociologie, XXVIII(3), 389. https://doi.org/10.2307/3321720

Herzog, T. R., Chen, H. C. and Primeau, J. S. (2002). Perception of the restorative potential of natural and other settings. Journal of Environmental Psychology, 22(3), 295-306. https://doi.org/10.1006/jevp.2002.0235

Heyl, S. B. (2001). Ethnographic Interviewing. In Handbook of Ethnography, edited by Paul. Atkinson, Amanda. Coffey, Sara. Delamont, John. Lofland and Lyn. Lofland, 369-383. London: Sage. https://doi.org/10.4135/9781848608337.n25

Hickman, C. (2013). To brighten the aspect of our streets and increase the health and enjoyment of our city': The National Health Society and urban green space in late-nineteenth century London. Landscape and Urban Planning, 118(0), 112-119. https:// doi.org/10.1016/j.landurbplan.2012.09.007

Hjalager, A.-M., Huijbens, E. H., Björk, P., Nordin, S., Flagestad, A. and Knútsson, Ö. (2008). Innovation Systems in Nordic Tourism Oslo, Norway: Norden - Nordic Innovation Centre.

Hjalager, A.-M. and Nordin, S. (2011). User-driven Innovation in Tourism-A Review of Methodologies. Journal of Quality Assurance in Hospitality \& Tourism, 12(4), 289-315. https:// doi.org/10.1080/1528008x.2011.541837

Hobbs, T. R. and Shelton, G. C. (1972). Therapeutic camping for emotionally disturbed adolescents. Psychiatric Services, 23(10), 298-301. https:// doi.org/10.1176/ps.23.10.298

Husk, K., Lovell, R., Cooper, C., Stahl-Timmins, W. and Garside, R. (2016). Participation in environmental enhancement and conservation activities for health and well-being in adults: A review of quantitative and qualitative evidence. Cochrane Database of Systematic Reviews, 5. https://doi.org/CD010351

Husk, K., Lovell, R. and Garside, R. (2018). Prescribing gardening and conservation activities for health and wellbeing in older people. Maturitas, 110, A1-A2. https://doi.org/10.1016/j.maturitas.2017.12.013

IBM. (2006). Five Barriers to Innovation: Key Questions and Answers. In IBM Global Business Series: IBM.

Jacobson, N. S., Martell, C. R. and Dimidjian, S. (2001). Behavioral Activation Treatment for Depression: Returning to Contextual Roots. Clinical Psychology: Science and Practice, 8(3), 255-270. https://doi.org/10.1093/clipsy.8.3.255

Joye, Y. and van den Berg, A. (2011). Is love for green in our genes? A critical analysis of evolutionary assumptions in restorative environments research. Urban Forestry \& Urban Greening, 10(4), 261-268. https://doi.org/10.1016/j.ufug.2011.07.004

Kaplan, S. and Kaplan, R. (1989). The Experience of Nature: A Psychological Perspective. New York: Cambridge University Press. 
Kaplan, S. and Talbot, J. F. (1983). Pyschological benefits of a wilderness experience. In Behavior and the Natural Environment edited by I. Altman and J. F. Wolwill, 163-203. New York: Plenum Publishers. https://doi.org/10.1007/978-1-4613-3539-9_6

Kaplan, S. (1995). The restorative benefits of nature: Toward an integrative framework. Journal of Environmental Psychology, 15(3), 169-182. https:/ / doi.org/10.1016/0272-4944(95)90001-2

Kellert, S. R. and Wilson, E. O. (1995). The Biophilia Hypothesis. New Edition ed. Washington D. C.: Island Press; New edition.

Kelly, C. (2010). Analysing Wellness Tourism Provision: A Retreat Operators' Study. Journal of Hospitality and Tourism Management, 17(01), 108-116. https://doi.org/10.1375/jhtm.17.1.108

Kelly, D. (2016). Working with Nature in Palliative Care. In Ecotherapy: Theory, Research and Practice, edited by Martin Jordan and Joe Hinds, 84-97. London: Palgrave. https://doi.org/10.1057/978-1-137-48688-2_7

Korpela, K. and Hartig, T. (1996). Restorative qualities of favorite places. Journal of Environmental Psychology, 16(3), 221-233. https://doi.org/10.1006/jevp.1996.0018

Kruger, K. A. and Serpell, A. (2006). Animal-assisted interventions in mental health. In Handbook on Animal-Assisted Therapy. Theoretical Foundations and Guidelines for Practice, edited by Fine. A. H., 21-38. San Diego: Academic Press Inc; 2nd Revised edition edition

Kull, K. (1998). Semiotic ecology: different natures in the semiosphere. Sign Systems Studies, 26, 344-371.

Kvale, S. and Brinkman, S. (2009). Interviews learning the craft of qualitative research interviewing. second ed. Thousand Oaks, California: Sage Publications, Inc.

Le Roux, B. and Rouanet, H. (2010). Geometric Data Analysis: From Correspondence Analysis to Structured Data Analysis. Dordrecht, The Netherlands: Kluwer academic publishers.

LeBesco, K. (2010). Neoliberalism, public health and the moral perils of fatness. Critical Public Health, 21(2), 153164. https://doi.org/10.1080/09581596.2010.529422

Lewis, C. A. (1990). Gardening as a healing process. In Meaning of Gardens: Idea, Place and Action edited by Mark Francis and Jr. Hester Randolph T., 244-251. Cambridge, MA.: Mit Pr

Lewis, C. A. (1996). Green Nature/Human Nature: the meaning of plants in our lives, Environment Human Condition. Illinois University of Illinois Press.

Lister, C., Reid, S., Musgrove, M. and Speirs, C. (2017). Pro-Active Minds Green Gym launch. Journal of Public Mental Health, 16(2), 88-90. https:/ / doi.org/10.1108/JPMH-03-2017-0007

Maller, C., Townsend, M., Pryor, A., Brown, P. and St Leger, L. (2006). Healthy nature healthy people: 'contact with nature' as an upstream health promotion intervention for populations. Health Promotion International, 21(1), 45-54. https://doi.org/10.1093/heapro/dai032

Miles, M. B. and Huberman, A. M. (1994). Qualitative data analysis: a sourcebook of new methods. Beverly Hills: Sage.

Mintel. (2011). Spa Tourism - International - October 2011. Available at: http://academic.mintel.com/display/545413/ (Accessed 30 January 2018)

Nadin, S. and Cassell, C. (2004). Using data matrices. In Essential guide to Qualitative Methods in Organizational Research, edited by Catherine. Cassell and Gillian. Symon, 271-287. London: Sage. https://doi.org/10.4135/9781446280119.n22

National Parks. (2012). Health. Available at: http://www.nationalparksengland.org.uk/home/policy/health (Accessed 09 January 2018)

Natural England. (2012). Walking for Health. Natural England. Available at: http://www.naturalengland.org.uk/ourwork/ enjoying/wfhfeature.aspx (Last Modified 24 May 2012, Accessed 09 January 2018)

Nightingale, F. (2010). Notes on Nursing Edited by Victor. Skretkowicz. New York: Springer. https://doi.org/10.1017/CBO9780511751349

Ormerod, E. (2008). Companion animals and offender rehabilitation - experiences from a prison therapeutic community in Scotland. Therapeutic Communities: the International Journal of Therapeutic Communities, 29(3), 285-296.

Owen, R. (2012). Quaterly Meeting. Plymouth.

Ozyilmaz, A. and Berg, D. (2004). Auditing entrepreneurial service innovations. International Journal of Services Technology and Management, 5(4), 394-429. https:// doi.org/10.1504/IJSTM.2004.004851

Ozyilmaz, A. and Berg, D. (2009). The role of Information Technology in service innovation in the two different quadrants of the service-process matrix. International Journal of Services Technology and Management, 11(3), 247 -271. https://doi.org/10.1504/IJSTM.2009.024092

Parker, S. (2004). Grass roots healing. Mental Health Practice, 7(8), 20-22. https://doi.org/10.7748/mhp2004.05.7.8.20.c1805

Parr, H. (2007). Mental health, nature work and social inclusion. Environment and Planning D: Society and Space, 25(3), 537-561. https://doi.org/10.1068/d67j 
Parsons, R. (1991). The potential influences of environmental perception on human health. Journal of Environmental Psychology, 11(1), 1-23. https://doi.org/10.1016/s0272-4944(05)80002-7

Partanen, U., Lilja, T., Kurppa, S. and Soini, K. (2006). Farming for Health in Finland. In Farming for Health: GreenCare Farming across Europe and the United States of America edited by Jan. Hassink and Majken. Van Dijk, 135-162. Dordrecht, Netherlands: Springe. https://doi.org/10.1007/1-4020-4541-7_11

Pearson, S. D. and Raeke, L. H. (2000). Patients' Trust in Physicians: Many Theories, Few Measures and Little Data. Journal of General Internal Medicine, 15(7), 509-513. https://doi.org/10.1046/j.1525-1497.2000.11002.x

Pikkemaat, B. (2008). Innovation in small and medium-sized tourism enterprises in Tyrol, Austria. The International Journal of Entrepreneurship and Innovation, 9(3), 187-197. https:// doi.org/10.5367/0000000008785096601

Porter, R. (1999). The Greatest Benefit to Mankind: A Medical History of Humanity New edition ed. New York Fontana Press.

Pretty, J., Peacock, J., Hine, R., Sellens, M., South, N. and Griffin, M. (2007). Green exercise in the UK countryside: Effects on health and psychological well-being and implications for policy and planning. Journal of Environmental Planning and Management, 50(2), 211-231. https:// doi.org/10.1080/09640560601156466

Pretty, J., Peacock, J., Sellens, M. and Griffin, M. (2005). The mental and physical health outcomes of green exercise. International Journal of Environmental Health Research, 15(5), 319-337. https://doi.org/10.1080/09603120500155963

Regan, C. L. and Horn, S. A. (2005). To nature or not to nature: Associations between environmental preferences, mood states and demographic factors. Journal of Environmental Psychology, 25(1), 57-66. https://doi.org/10.1016/j.jenvp.2005.01.001

Reynolds, V. (2002). Well-being comes naturally: an evaluation of the BTCV Green Gym at Portslade, East Sussex. In Report No. 17. Oxford: OCHRAD.

Risku-Norja, H. and Yli-Viikari, A. (2008). School Goes to the Farm - action model for rural-based sustainability education. Innovation Systems and Rural Development Proceedings from 10th Annual Conference, Nordic-Scottish University for Rural and Regional Development, Denmark, Horsholm.

Rosendahl. (2013). Finnish government agrees more long-term welfare cuts. Reuters. http://uk.reuters.com/article/2013/11/29/uk-finland-reforms-idUKBRE9AS0PP20131129 (Accessed 09 November 2017)

Rush, B. (2003). Medical Inquiries and Observations upon Diseases of the Mind (1835). 5th ed. Charles Town, MA: Harvard College Library facsimile.

Russell, K. C. (1999). Theoretical Basis, Process and Reported Outcomes of Wilderness Therapy as an Intervention and Treatment for Problem Behaviour in Adolescents. PhD, College of Graduate Studies, University of Idaho.

Russell, K. C. (2006a). Brat camp, boot camp, or .......? Exploring wilderness therapy program theory. Journal of Adventure Education \& Outdoor Learning, 6(1), 51-67. https:// doi.org/10.1080/14729670685200741

Russell, K. C. (2006b). Evaluating the Effects of the Wendigo Lake Expedition Program on Young Offenders. Youth Violence and Juvenile Justice, 4(2), 185-203. https:/ /doi.org/10.1177/1541204006286317

Russell, K. C. and Phillips-Miller, D. (2002). Perspectives on the Wilderness Therapy Process and Its Relation to Outcome. Child and Youth Care Forum, 31(6), 415-437. https://doi.org/10.1023/a:1021110417119

Sempik, J. and Aldridge, J. (2005). Social and therapeutic horticulture in the UK: The growing together study. Loughborough University. https://doi.org/10.1007/1-4020-4541-7_12

Sempik, J. and Aldridge, J. (2006). Care farms and care gardens: horticulture as therapy in the UK. In Farming for Health, edited by J. Hassink and M. Van Dijk, 147-161. Dordrecht: Springer.

Sempik, J., Aldridge, J. and Becker, S. (2002). Social and therapeutic horticulture: Evidence and messages from research. Thrive in association with the Centre for Child and Family Research.

Sempik, J., Hine, R. and Wilcox, D. (2010). Green Care: A conceptual Framework, A Report of the Working Group on the Health Benefits of Green Care. In COST Action 866 Green Care in Agriculture. Loughborough Univerity: Loughborough: Centre for Child and Family Research.

Sims, J., Galea, N., Taylor, N., Dodd, K., Jespersen, S., Joubert, L. and Joubert, J. (2009). Regenerate: assessing the feasibility of a strength-training program to enhance the physical and mental health of chronic post stroke patients with depression. International Journal of Geriatric Psychiatry, 24(1), 76-83. https://doi.org/10.1002/gps.2082

Smyth, F. (2005). Medical geography: therapeutic places, spaces and networks. Progress in Human Geography, 29(4), 488-495. https://doi.org/10.1191/0309132505ph562pr

Soini, K. (2012). Development of Green Care in Finland. In Green Care in the Nordic countries - a research field in progress, edited by Bente Berget., Lena Lidfors., Anna María Pálsdóttir., Katriina Soini and Karen Thodberg., 13-15. Trondheim: HealthUMB, Norwegian University of Life Sciences. 
Stathopoulou, G., Powers, M. B., Berry, A. C., Smits, J. A. J. and Otto, M. W. (2006). Exercise Interventions for Mental Health: A Quantitative and Qualitative Review. Clinical Psychology: Science and Practice, 13(2), 179-193. https://doi.org/10.1111/j.1468-2850.2006.00021.x

Steigen, A. M., Kogstad, R. and Hummelvoll, J. K. (2015). Green Care services in the Nordic countries: an integrative literature review. European Journal of Social Work (1-23). https://doi.org/10.1080/13691457.2015.1082983

Stigsdotter, A. U. and Grahn, P. (2002). What makes a garden a healing garden? Journal of Therapeutic Horticulture, 13, 60-69.

Straede, C. M. and Gates, R. G. (1993). Psychological Health in a Population of Australian Cat Owners. Anthrozoos: A Multidisciplinary Journal of the Interactions of People \& Animals, 6(1), 30-42. https://doi.org/10.2752/089279393787002385

Strandli, E. H. A. (2007). Den beste dagen på mange år (the best day in years). Tønsberg, Norway: Forlaget Aldring og helse.

Swedberg, R. (2011). The Economic Sociologies of Pierre Bourdieu. Cultural Sociology, 5(1), 67-82. https://doi.org/10.1177/1749975510389712

Tesch, R. (1990). Qualitative research: analysis types and software tools. London: The Falmer Press.

Thompson, C. J., Boddy, K., Stein, K., Whear, R., Barton, J. and Depledge, M. H. (2011). Does Participating in Physical Activity in Outdoor Natural Environments Have a Greater Effect on Physical and Mental Wellbeing than Physical Activity Indoors? A Systematic Review. Environmental Science \& Technology, 45(5), 1761-1772. https://doi.org/10.1021/es102947t

Thorsheim, P. (2006). Inventing Pollution: Coal, Smoke and Culture in Britain since 1800 Series in Ecology \& History. Ohio: Ohio University Press.

Tidd, J. and Bessant, J. (2009). Managing Innovation: Integrating Technological, Market and Organizational Change 4th ed. Chichester: John Wiley \& Sons.

Tidd, J. and Bessant, J. (2011). Innovation and Entrepreneurship. Chichester: John Wiley \& Sons.

Townsend, M. (2006). Feel blue? Touch green! Participation in forest/woodland management as a treatment for depression. Urban Forestry \& Urban Greening, 5(3), 111-120. https://doi.org/10.1016/j.ufug.2006.02.001

Ulrich, R. S. (1983). Aesthetic and affective response to natural environment. Human Behavior \& Environment: Advances in Theory \& Research, 6(85).

Vaughan, D. (2008). Bourdieu and Organizations: The Empirical Challenge. Theory and Society, 37(1), 65-81. https://doi.org/10.2307/40211026

Webb, J., Schirato, T. and Danaher, G. (2002). Understanding Bourdieu London: Sage Publications.

Wheeler, B. W., White, M., Stahl-Timmins, W. and Depledge, M. H. (2012). Does living by the coast improve health and wellbeing? Health \& Place, 18(5), 1198-1201. https://doi.org/10.1016/j.healthplace.2012.06.015

White, M. P., Pahl, S., Wheeler, B. W., Fleming, L. E. F. and Depledge, M. H. (2016). The 'Blue Gym': What can blue space do for you and what can you do for blue space? Journal of the Marine Biological Association of the United Kingdom, 96(1), 5-12. https://doi.org/10.1017/S0025315415002209

White, M., Smith, A., Humphryes, K., Pahl, S., Snelling, D. and Depledge, M. (2010). Blue space: The importance of water for preference, affect and restorativeness ratings of natural and built scenes. Journal of Environmental Psychology, 30(4), 482-493. https://doi.org/10.1016/j.jenvp.2010.04.004

White, M., Hignett, A. and Pahl, S. (2011). Surf to Success: Outcomes Can Learning to Surf Promote Individual and Environmental Well-Being? A Preliminary Assessment of Global Boarders' Surf to Success Programme. European Centre for Environment and Human Health.

Williams, A. M., Shaw, G. and Greenwood, J. (1989). From tourist to tourism entrepreneur, from consumption to production: evidence from Cornwall, England. Environment \& Planning 12, 1639-1653. https://doi.org/10.1068/a211639

Wilson, E. O. (1986). Biophilia. The Human Bond with Other Species. Cambridge MA: Harvard University Press.

Wilson, S. J. and Lipsey, M. W. (2000). Wilderness challenge programs for delinquent youth: a meta-analysis of outcome evaluations. Evaluation and Program Planning, 23(1), 1-12. https://doi.org/10.1016/S01497189(99)00040-3

Wood, L., Giles-Corti, B. and Bulsara, M. (2005). The pet connection: Pets as a conduit for social capital? Social Science \& Medicine, 61(6), 1159-1173. https://doi.org/10.1016/j.socscimed.2005.01.017

Woods, B., Spector, A. E., Jones, C. A., Orrell, M. and Davies, S. P. (2005). Reminiscence therapy for dementia. Cocbrane Database of Systematic Reviews, 2005(2) (Art. No.: CD001120). https://doi.org/10.1002/14651858.CD001120.pub2

Woods, R. T. (1998). Reminiscence as communication. In Reminiscence in dementia care, edited by P. Schweitzer, $143-$ 148. London: Age Exchange. 
Wuppertal, Institute and et al. (2009). Eco-innovation - putting the EU on the path to a resource and energy efficient economy. edited by Raimund Bleischwitz., Bettina Bahn-Walkowiak., Wolfgang Irrek., Phillip Schepelmann., Friedrich Schmidt-Bleek., Stefan Giljum., Stephan Lutter., Lisa Bohunovski., Friedrich Hinterberger., Elizabeth Hawkins., Michael Kuhndt., Nadine Pratt., Arnold Black., Geert van der Veen. and Birgit Eggl.: European Parliament's committee on Industry, Research and Energy (ITRE).

\section{APPENDIX 1}

\section{Interview Schedule for Entrepreneurs}

\section{EXXNEESTIY of |MEDICAL \\ Participant information}

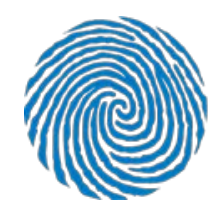

Name:

Name of organisation:....

Position in Organisation:.

Length of service:

\section{Strategy}

Q1. What is the mission of your organisation and what values are these based on?

Q2. What are the main drivers and motivations for your organisation?

Q3. What is your core product/ service and how does it relate to the natural environment?

Q4. Prior to launching a new product/ service how did you assess market demand for your product or service? (Arundel and Kemp, 2009)

Q5. Do your products or services have a target audience? What is it?

Q6. What are the motivations for using the environment in your product/service?

\section{Processes}

Q7. How important is it to your organisation to make time for learning new skills and additional training? (IBM, 2006)

\section{Organisation}

Q8. How do you measure the benefits / outcomes of your organisation and the products and services you offer? (IBM, 2006)

Q9. Which factors do you think draws most people to your company and the product and service you offer?

\section{Linkages}

Q10. How have external networks affected your product/service, how important are they? (IBM, 006) (Rayment, 2010)

Q11. How important is it that the people you work with, employees, suppliers etc. share your values? (IBM, 2006)

Q12. Do you see a link between nature and innovation? (Orcutt and AlKadri, 2009)

\section{Learning}

Q13. How did you come up with the ideas to use the natural environment in your organisation or services?

Q14. How long have you been offering services/products that use the environment?

Q15. Finally, do you have any other thoughts you would like to add about what we have been discussing?

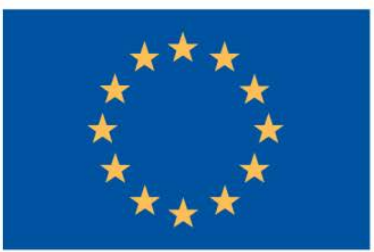

European Union European Social Fund Investing in jobs and skills

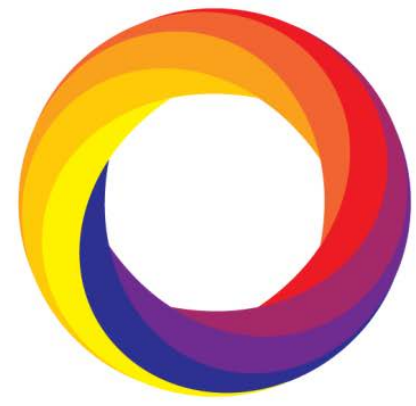

\section{convergence for economic transformation}




\section{APPENDIX 2}

Interview Schedule for Academics
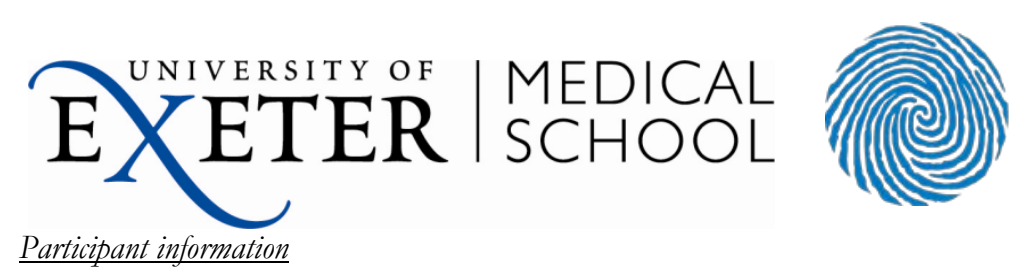

Name:

Name of organisation:.

Position in Organisation:.

Length of service:

\section{Strategy}

Q1. Are there a common mission that you find in health and well-being organisations? Or common values?

Q2. What are the main drivers and motivations for enterprises working in health and well-being in your context?

Q3. What are the main products and services that you focus on in your research? How do these relate to the natural environment?

Q4. How do you think organisations assess market demand before launching a product or service? (Arundel and Kemp, 2009)

Q5. Do you know of any example in your main area of interest where products or services have been initially targeted at one group? and then refined to attract a different target audience?

Q6. What motivates the organisations to use the environment in health and wellbeing products/ services?

\section{Processes}

Q7. From the case studies and examples you know of how important do you think it is for organisations to make time for learning new skills and additional training? (IBM, 2006)

\section{Organisation}

Q8. From your experience how do organisations measure the benefits/outcomes health and well-being products and services? (IBM, 2006)

Q9. Which factors do you think draws most people to health and well-being companies and the product and services

\section{Linkages}

Q10. In your opinion how important are external networks in the health and well-being industry? (IBM, 2006) (Rayment, 2010)

Q11. How important is it that the people in an organisation, employees, suppliers etc. share the same values? and how common is it? (IBM, 2006)

Q12. Do you see a link between nature and innovation? (Orcutt and AlKadri, 2009)

\section{Learning}

Q13. How do you think organisations come up with the ideas to use the natural environment?

Q14. What is the history of using natural environments in health and well-being in your country? How do you think the attitude of the public has change to this idea?

Q15. Finally, do you have any other thoughts you would like to add about what we have been discussing?

Thank you for your time!

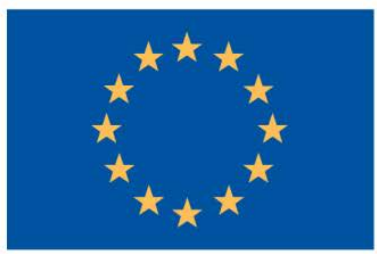

European Union European Social Fund Investing in jobs and skills

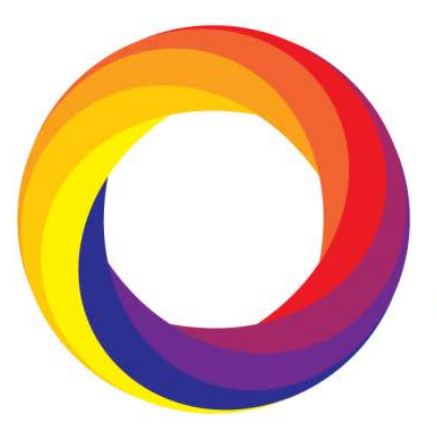

\section{convergence for economic transformation}

